\title{
LETTER
}

\section{The triage dilemma: opening Pandora's box... ever so slowly}

\author{
Frederick M Burkle, Jr* \\ See related research by Christian et al., http://ccforum.com/content/13/5/R170
}

I applaud the efforts by Michael Christian and colleagues [1] in taking on the difficult dilemmas surrounding triage management and training tied to surge capacity and resource allocation within intensive care settings during pandemics. Studies on triage protocols arose primarily from critical care professionals awakened to those responsibilities during severe acute respiratory syndrome and then re-challenged during the current H1N1 pandemic [2-4].

In reality, intensive care units with their professional staff and high-tech equipment represent a major limiting factor for most communities. The most plausible scenario for a viral pathogen of greater severity and lethality is that emergency departments and hospital wards will be deluged with critical care patients, the challenge being how to provide 'opportunities for survival' by transferring some semblance of critical care services and expertise to these 'non-critical care' settings. Discipline-directed triage management protocols will only be as important as the manner in which these tertiary level algorithms can be integrated into a larger system-wide triage scheme that begins at the primary triage care level and ends with whatever additional resources a regional support system can mobilize. Many 'uncomfortable but real' decisions that have not, to date, been operationalized at the local level will be made.

Triage management requires an infrastructure, such as health emergency operations centers (HEOCs), where central triage committees, operationalized ethical resources, palliative care guidance, data collection and analysis, and communication capacities provide high-level situational awareness for simultaneously initiating triage and modifying protocols at all health facilities and their individual triage teams [5]. While attempts to provide independent hospital-centric plans are noble, they do not

*Correspondence: fburkle@hsph.harvard.edu

Harvard Humanitarian Initiative, Harvard School of Public Health, 14 Story Street, 2nd Floor, Cambridge, MA 02138, USA solve what ultimately requires an integrated populationbased system-wide solution [6].

Triage is an imperfect but necessary 'art and science' whether based on good clinical judgment or informed by protocols that attempt to direct resources to those most likely to benefit. Critical care studies opened Pandora's box. What follows requires much more input from other disciplines and society itself. Although it may first seem like one is trespassing professional boundaries, the investment in integrated preparedness and effective surge strategies, including system-wide triage, is crucial to minimize the need for rationing at all levels of care.

Competing interests

The author declares that he has no competing interests.

Published: 19 January 2010

\section{References}

1. Christian MD, Hamielec C, Lazar NM, Wax RS, Griffith L, Herridge MS, Lee D, Cook DJ: A retrospective cohort pilot study to evaluate a triage tool for use in a pandemic. Crit Care 2009, 13:R170.

2. Christian MD, Hawryluck L, Wax RS, CookT, Lazar NM, Herridge MS, Muller MP, Gowans DR, Fortier W, Burkle FM: Development of a triage protocol for critical care during an influenza pandemic. CMAJ 2006, 175:1377-1381.

3. Kumar A, Zarychanski R, Pinto R, Cook DJ, Marshall J, Lacroix J, Stelfox T, Bagshaw S, Choong K, Lamontagne F, Turgeon AF, Lapinsky S, Ahern SP, Smith O, Siddiqui F, Jouvet P, Khwaja K, McIntyre L, Menon K, Hutchison J, Hornstein D, Joffe A, Lauzier F, Singh J, Karachi T, Wiebe K, Olafson K, Ramsey C, Sharma S, Dodek P; Canadian Critical Care Trials Group H1N1 Collaborative: Critically ill patients with 2009 influenza A (H1N1) infection in Canada. JAMA 2009, 302:1872-1879.

4. Devereaux AV, Dichter JR, Christian MD, Dubler NN, Sandrock CE, Hick JL, Powell T, Geiling JA, Amundson DE, Baudendistel TE, Braner DA, Klein MA, Berkowitz KA, Curtis JR, Rubinson L; Task Force for Mass Critical Care: Definitive care for the critically ill during a disaster: a framework for allocation of scarce resources in mass critical care. Task Force for Mass Critical Care. Chest 2008, 133 (5 Suppl):51S-66S.

5. Burkle FM Jr., Hsu EB, Loehr M, Christian MD, Markenson D, Rubinson L, Archer FL: Definition and functions of health unified command and emergency operations centers for large-scale bioevent disasters within the existing ICS. Disaster Med Public Health Prep 2007, 1:135-141.

6. Frolic A, Kata A, Kraus P: Development of a critical care triage protocol for pandemic influenza: integrating ethics, evidence and effectiveness. Healthc Q 2009, 12:56-64. 